\title{
Energy budgets' formation based on incomplete data
}

\author{
Valery Litvak $^{1}{ }^{*}$, Galina $\mathrm{Klimova}^{1}$, and Veronika Morozova ${ }^{1}$ \\ ${ }^{1}$ National Research Tomsk Polytechnic University, 634050 Tomsk, Russia
}

\begin{abstract}
The universal technique of the current energy budget calculation is recommended for several periods of time. Basing on the data of annual energy budget and considering the plant's features, social, climatic and other conditions, correcting factors are calculated to estimate energy resources consumption for the day, week, month and year. Shortterm current energy budget supports important financial, trade, logistic, organizational and other control directions. The developed technique is applicable for subnational entities and industrial enterprises in order to increase level of energy resources consumption planning and forecasting as well as bills' optimization.
\end{abstract}

Govermental statistic witnessing provides filling statistic data to form region energy budget based on several census report form [1-4].

According to facts it takes about half-year from information acquisition of energy resources using to energy budget formation. Of course, it stops effective sampling and energy efficiency management.

Provided approach makes possible to form and analyze energy budget during a process, it gives opportunities to take energy-saving and efficiency upgrading measures.

Principle of such method is to develop an energy budget model based on using detected internal regularities of historic budgets with incomplete or even irreconcilable data of current period. Statistic budget formation remains to be main machine to improve accuracy and adequacy.

Such approach is clear because of following consideration:

$\checkmark \quad$ Immeasurable elements' calculations are made by detected internal budget relations;

$\checkmark \quad$ Elements' numeric value tolerance definition is defined by errors of energy flow changes and mutual coupling factor calculation;

$\checkmark \quad$ If desired successive refinement of energy budget elements' numeric values design ratios opportunity can be saved.

For approach simplication of budget internal relations formation nonlinear relations are simulated as linear, and multifactorial restrictions are simulated doubled restrictions.

Correlation based on linear equation is formed with direct relationship presence, where individual result intimately increase or decrease with factor changes. It is defined in the shape of following equation [7]:

$$
y_{x}=a_{0}+a_{1} x,
$$

\footnotetext{
* Corresponding author: litvak@tpu.ru
} 
where $y$ - resulting characteristic individual value, $x$ - factor characteristic individual value, $a_{0}, a_{1}$ - equation parameters, $y_{x}--$ resulting characteristic theoretical value.

Equation parameters $a_{0}$ and $a_{1}$ are defined by the way of least square method:

$$
\left\{\begin{array}{l}
\sum y=n a_{0}+a_{1} \sum x, \\
\sum y x=a_{0} \sum x+a_{1} \sum x^{2} .
\end{array}\right.
$$

Parameter $a_{0}$ is defined by the following way:

$$
a_{0}=\frac{\sum y \sum x^{2}-\sum y x \sum x}{n \sum x^{2}-\sum x \sum x} .
$$

Consequently $a_{1}$

$$
a_{1}=\frac{n \sum y x-\sum x \sum y}{n \sum x^{2}-\sum x \sum x} .
$$

Closeness correlation changes are performed by calculation of linear factor of correlation, theoretical correlation relation and correlation index.

Adequacy and correctness of closeness correlation measuring operation are estimated by Fisher's ratio test.

Empirical Fisher's ratio test value $F_{\ni}$ is compared to critical (tabular $F_{\mathrm{T}}$ ) with significance level 0.01 or 0.05 and number of degrees of freedom $(m-1),(n-m)$. If $F_{\ni}>F_{\mathrm{T}}$, correlation empirical estimator is regarded to be significant.

Linear regression equation factors significancy is estimated with Student's $t$-test $(n<30)$.

Empirical Student's $t$-test value is compared to critical (tabular) with significance level 0.01 or 0.05 and number of degrees of freedom $(n-2)$. If empirical value is bigger than tabular, correlation empirical estimator is regarded to be significant [7].

Done estimation results afford to predicate that elements have relations is proved on the whole range of energy resources. regression factors significancy is checked by Fisher's ratio test.

Nowadays there has been a resumed interest to the energy budget as a tool or analyzing and planning of power generation, for quality control of energy conservation and energy resources efficiency enhancement measures [5-6].

Thus, it is of vital importance to develop approaches towards energy budget calculation for short period of time. This issue has a great value in case of development potential, plotting graphs of product transportation and fuel supply, assessing possibilities of energy resources demand coverage for severe conditions e.g. winter peak and summer low load, repair and maintenance schedule, specific climatic conditions (waterflood, hurricane, fallout and etc.), anthropogenic and natural disasters.

It is rational to divide current energy resources budgets into following time steps: hour, shift, civil day, operating day, weekends and public holidays, weeks with different number of working days and holidays, month, year quarter, heating and non-heating seasons, repair period, annual accounting period.

It is not feasible to build energy budgets for ultra-short periods of time (less than one hour). Methodically it can be done by formulated approaches, but practically such budgets have not a great value. Table 1 shows energy budget of reinforced concrete plant for one year. 
Basis for mentioned below calculating is annual energy budget of reinforced concrete plant.

Volumes of energy resources are presented in own units for each, because it is not feasible to present the resources in reference fuel units. Moreover service and drinkable water consumption is shown as well. Water is not an energy resource, but on the other hand, water-supply system is operated by chief power engineer service crew.

Current energy budget for short period of time supports financial, commercial, logistic, organizational and other branches' basis of controlling [3, 8]. Current energy budget could be used for independent assessment of energy production, efficiency of power saving and other cases.

Average calculations of assigned year energy consumption are not difficult if we do not consider short periodical energy budgets structure perturbations:

$$
A_{t}=\int_{0}^{t} P_{t} \cdot d t \cdot \frac{A_{\text {year }}}{N_{t}} \cdot \Delta t,
$$

where $P_{t}$ - current power, $\mathrm{kW}, A_{\text {year }}$ - annular consumption, kilowatt hour, $T$ - basis time duration, hour, $\Delta t$ - current period duration, hour, $N$ - number of equal current time intervals per one year [4]. In case of known plant energy consumption per one year (40000 Ths. kilowatt hour) average short periodical consumption volumes will be calculated as follows.

There is actual difference between energy resources use for short period of time and average for one year. Thus it is necessary to adjust temperature, social, process and other factors. Element value adjustment should be done in the following way:

$$
A_{k}=A_{a v} \cdot\left(1+k_{1} \cdot k_{2} \cdot k_{3} \cdot k_{4}\right)
$$

where $A_{k}$ - current element value, $A_{a v}$ - average element value, $k_{1}$ - correcting factor considering energy resources volumes of operating days and holidays, $k_{2}$ - correcting factor considering demand's increment between start and end of the year; $k_{3}$ - correcting factor considering energy resources consumption depending on air temperature, $k_{4}-$ correcting factor considering energy resources consumption between heating and nonheating seasons.

Energy consumption ratio of holidays and operating days with correcting factor $k_{1}$ approaches $0.5: 1$. This ratio between holidays and operating days for one week reinforced concrete plant operation equaled $0.55: 1$.18. In relation to year average plant measurements level showed following $k_{1}$ values (Table 1).

Table 1. Correction factor $k_{1}$.

\begin{tabular}{|c|c|c|c|c|}
\hline $\begin{array}{c}\text { Correction factor } k_{1}, \\
\text { relative unit }\end{array}$ & Electrical energy & Thermal energy & Gas & Water \\
\hline Operating days & 1.15 & 1.1 & 1.07 & 1.12 \\
\hline $\begin{array}{c}\text { Weekends and public } \\
\text { holiday }\end{array}$ & 0.55 & 0.75 & 0.825 & 0.7 \\
\hline
\end{tabular}

Correction factor $k_{2}$ considering demand's increment between start and end of the year is defined as: 


$$
k_{2}=1+k_{\text {in }} \cdot \frac{i}{365}
$$

where $k_{\text {in }}=0,02 \div 0,04$ - average incremental growth of demand equal $2-4 \%$ per year, $i-$ number of the date starting from $1^{\text {st }}$ of January.

Air temperature correction factor $k_{3}$ describes energy resources incremental growth with air temperature lower than $+10^{\circ} \mathrm{C}$ in relation to average temperature for same period of many years. In some cases, temperature may be close to zero degrees. Temperature reference scale origin is shifted to the point of $-100^{\circ} \mathrm{C}$ to avoid division by zero. Then:

$$
k_{3}=\frac{100-\Theta_{d}}{100-\Theta_{a v}},
$$

where $\Theta_{d}$ - desired air temperature of design day, ${ }^{0} \mathrm{C}, \Theta_{a v}$ - average long-term temperature of this day, ${ }^{0} \mathrm{C}$.

Correction factor $k_{4}$ characterizes energy resources consumption between heating and non-heating seasons. It is important to include this factor into calculations because there is a great difference in heat and fuel consumption for both seasons. As a rule difference water and electrical energy consumption is small.

Centralized annual heat and fuel consumption comprises the following:

$$
Q=Q_{\text {heat }}+Q_{\mathrm{hws}}+Q_{p r}
$$

where $Q_{\text {heat }}$ - heat consumption for heating, Gcal, $Q_{\text {hws }}$ - hot water supply, Gcal, $Q_{p r}-$ heat consumption for process requirements, Gcal.

Thermal energy for heating $Q_{\text {heat }}$ is supplied only during heating season, hot water supply $Q_{\text {hws }}$ - all year round, and $Q_{p r}$ according to operational program. Unfortunately, there is no any division of these three flows in official statistics. In calculations hot water supply system volume in comparison with heating accounts for $10-12 \%$. Throwing away $Q_{p r}$ due to its uncertainty, we may assume that:

$$
\begin{gathered}
Q=Q_{\text {heat }}+Q_{\text {hws }}=Q_{\text {heat }}+0.12 Q_{\text {heat }}=1.12 Q_{\text {heat }}, \\
Q_{\text {heat }}=\frac{Q_{\text {heat }}+Q_{\text {hws }}}{1.12}=0.89 \cdot\left(Q_{\text {heat }}+Q_{\text {hws }}\right), \\
Q_{\text {heat }}=\frac{Q_{\text {heat }}+Q_{\text {hws }}}{1.12}=0.89 Q .
\end{gathered}
$$

Daily average heat transmission for heating volume during heating season is:

$$
q_{\mathrm{av}}^{\text {heat }}=\frac{0.89 Q}{235}=3.79 \cdot 10^{-3} Q
$$

and hot water supply all year round:

$$
q_{\mathrm{av}}^{h w s}=(1-0.89) \cdot \frac{Q}{365}=0.29 \cdot 10^{-3} Q
$$

Daily heat supply during heating season: 


$$
q_{\text {day }}=3.79 \cdot 10^{-3} Q+0.29 \cdot 10^{-3} Q=4.08 \cdot 10^{-3} Q,
$$

and during non-heating season:

$$
q_{\text {day }}=0.29 \cdot 10^{-3} Q
$$

Correspondingly, the correcting factor $k_{4}$ during heating and non-heating seasons is equal to:

$$
\begin{aligned}
& k_{4}=4.08 \cdot 10^{-3} \cdot 235=0.9588, \\
& k_{4}=0.29 \cdot 10^{-3} \cdot 130=0.0377 .
\end{aligned}
$$

This correcting factor for electrical energy and water supply can be taken as 1 .

\begin{tabular}{|c|c|c|c|c|c|c|c|c|}
\hline \multirow{2}{*}{$\begin{array}{l}\text { Current } \\
\text { period }\end{array}$} & \multicolumn{4}{|c|}{$\begin{array}{c}k_{1}, k_{\mathrm{o}}-\text { operating days } \\
k_{\mathrm{h}}-\text { holidays }\end{array}$} & \multirow[b]{2}{*}{$k_{2}$} & \multirow[b]{2}{*}{$k_{3}$} & \multicolumn{2}{|c|}{$k_{4}$ heat and fuel } \\
\hline & $\begin{array}{c}\text { Electrical } \\
\text { energy }\end{array}$ & $\begin{array}{l}\text { Thermal } \\
\text { energy }\end{array}$ & Gas & Water & & & $\begin{array}{l}\text { Heating } \\
\text { season }\end{array}$ & $\begin{array}{c}\text { Non- } \\
\text { heating } \\
\text { season }\end{array}$ \\
\hline $\begin{array}{c}\frac{\text { Hour }}{k_{\mathrm{o}}} \\
k_{\mathrm{h}}\end{array}$ & $\begin{array}{l}1.15 \\
0.55\end{array}$ & $\begin{array}{c}1.1 \\
0.75\end{array}$ & $\begin{array}{c}1.07 \\
0.875\end{array}$ & $\begin{array}{l}1.12 \\
0.7\end{array}$ & $1+k_{\text {in }} \cdot \frac{i}{365}$ & $\frac{100-\Theta_{d}}{100-\Theta_{a v}}$ & 0.9588 & 0.0377 \\
\hline $\begin{array}{l}\frac{\text { Day }}{k_{\mathrm{o}}} \\
k_{\mathrm{h}}\end{array}$ & $\begin{array}{l}1.15 \\
0.55 \\
\end{array}$ & $\begin{array}{c}1.1 \\
0.75 \\
\end{array}$ & $\begin{array}{c}1.07 \\
0.875 \\
\end{array}$ & $\begin{array}{l}1.12 \\
0.7 \\
\end{array}$ & $1+k_{\text {in }} \cdot \frac{i}{365}$ & $\frac{100-\Theta_{d}}{100-\Theta_{a v}}$ & 0.9588 & 0.0377 \\
\hline$\underline{\text { Week }}$ & & $\frac{n_{O}}{7}+\frac{k_{h}}{7}$ & $\frac{\left.7-n_{O}\right)}{7}$ & & $1+k_{\text {in }} \cdot \frac{i}{52}$ & $\frac{100-\Theta_{d}}{100-\Theta_{a v}}$ & 0.9588 & 0.0377 \\
\hline$\underline{\text { Month }}$ & & $\frac{n_{O}}{n}+\frac{k_{h}}{}$. & $\frac{\left.l_{a}-n_{O}\right)}{n_{a}}$ & & $1+k_{i n} \frac{j}{12}$ & $\frac{100-\Theta_{d}}{100-\Theta_{a v}}$ & 0.9588 & 0.0377 \\
\hline $\begin{array}{l}\text { Heating } \\
\text { season }\end{array}$ & & $\frac{n_{O}}{t}+\frac{k_{h}}{}$. & $\frac{\left.a_{a}-n_{O}\right)}{n_{a}}$ & & $1+k_{\text {in }} \frac{n_{a}}{365}$ & $\frac{100-\Theta_{d}}{100-\Theta_{a v}}$ & 0.9588 & 0.0377 \\
\hline $\begin{array}{l}\begin{array}{c}\text { Non- } \\
\text { heating }\end{array} \\
\text { season } \\
\end{array}$ & & $\frac{n_{O}}{t}+\frac{k_{h}}{}$. & $\frac{\left.n_{a}-n_{O}\right)}{n_{a}}$ & & $1+k_{i n} \frac{n_{a}}{365}$ & $\frac{100-\Theta_{d}}{100-\Theta_{a v}}$ & 0.9588 & 0.0377 \\
\hline
\end{tabular}

Correction factors for other periods of time are defined the same way. Table 2 shows correcting factors' values for accepted design conditions.

Table 2. Correcting factors' values

*Foot-note: $k_{\mathrm{O}}$ - operating load factor, $k_{h}$ - weekend and public holidays load factor, $k_{\Pi}-$ increment load factor of the whole year, $\Theta_{d}$ - desired temperature of period, $\Theta_{a v^{-}}$ average temperature of period, $i$ - day number of the year, $n_{O}$ - operating days number of period, $j$ - week number starting from the beginning of the year, $n_{a}$-day quantity of the period, $e-$ month number starting from the beginning of the year.

Further example of current day budget for one operating day of heating season is calculated.

Basic data. $13^{\text {th }}$ of February is forty fourth operating day starting from the beginning of the year. Increment rate is $k_{i n}=2 \%$. Heating season. Average day temperature $-14.5^{0} \mathrm{C}$, desired temperature $-16^{\circ} \mathrm{C}$. 
Table 3. Current daily energy budget of reinforced concrete plant (13th of February)

\begin{tabular}{|c|c|c|c|c|c|c|c|c|}
\hline \multirow{3}{*}{$\begin{array}{c}\text { Balance } \\
\text { items' } \\
\text { nomenclature }\end{array}$} & \multicolumn{2}{|c|}{ Gas } & \multicolumn{2}{|c|}{ Electrical energy } & \multicolumn{2}{|c|}{ Thermal energy } & \multicolumn{2}{|c|}{ Water } \\
\hline & $\begin{array}{c}\text { Calculate } \\
\mathrm{d}\end{array}$ & Real & $\begin{array}{c}\text { Calculate } \\
\text { d }\end{array}$ & Real & $\begin{array}{c}\text { Calculate } \\
\text { d }\end{array}$ & $\begin{array}{c}\text { Rea } \\
1\end{array}$ & $\begin{array}{c}\text { Calculate } \\
\mathrm{d}\end{array}$ & Real \\
\hline & Ths.m3 & $\begin{array}{c}\text { Ths.m } \\
3\end{array}$ & $\begin{array}{l}\text { Ths. } \\
\text { kWatt } \\
\text { hour }\end{array}$ & $\begin{array}{c}\text { Ths.kWa } \\
\text { tt hour }\end{array}$ & Gcal & $\begin{array}{c}\text { Gca } \\
1\end{array}$ & $\begin{array}{l}\text { Cubic } \\
\text { meter }\end{array}$ & $\begin{array}{c}\text { Cubi } \\
\text { c } \\
\text { mete } \\
\text { r }\end{array}$ \\
\hline Generation & - & - & - & - & 73.94 & 74 & 30.1 & 30 \\
\hline $\begin{array}{l}\text { Received } \\
\text { from other } \\
\text { source }\end{array}$ & 11.36 & 11.4 & 123.7 & 123 & - & - & 105.5 & 106 \\
\hline $\begin{array}{c}\text { Total } \\
\text { consumption }\end{array}$ & 11.36 & 11.4 & 123.7 & 123 & 73.94 & 74 & 135.6 & 136 \\
\hline $\begin{array}{c}\text { Administrati } \\
\text { on building }\end{array}$ & - & - & 3.59 & 3.7 & 1.02 & 1.0 & 4.07 & 4 \\
\hline $\begin{array}{c}\text { Reinforceme } \\
\text { nt shop }\end{array}$ & 0.57 & 0.6 & 5.44 & 5.5 & 1.71 & 1.7 & 6.78 & 7 \\
\hline $\begin{array}{c}\text { Welding } \\
\text { shop }\end{array}$ & 0.35 & 0.3 & 21.4 & 20 & 1.02 & 1.0 & 4.07 & 4 \\
\hline $\begin{array}{c}\text { Polygons } 1, \\
2,3\end{array}$ & - & - & 8.17 & 8.2 & 34.13 & 35 & 20.34 & 20 \\
\hline $\begin{array}{c}\text { Formwork } \\
\text { shop }\end{array}$ & - & - & 4.58 & 4.5 & 1.27 & 1.3 & 4.52 & 6 \\
\hline Forging shop & 1.13 & 1.0 & 10.89 & 11 & 0.68 & 0.5 & 2.71 & 3 \\
\hline $\begin{array}{l}\text { Asphalt- } \\
\text { concrete } \\
\text { shop }\end{array}$ & 0.35 & 0.3 & 13.61 & 14 & 1.02 & 1.0 & 4.07 & 4 \\
\hline $\begin{array}{c}\text { Compressor } \\
\text { room }\end{array}$ & 0.23 & 0.2 & 7.3 & 7 & 2.04 & 2.0 & 8.14 & 8 \\
\hline $\begin{array}{l}\text { Crushing } \\
\text { shop } 1,2\end{array}$ & 0.46 & 0.5 & 18.68 & 20 & 3.41 & 3.5 & 13.56 & 13 \\
\hline $\begin{array}{c}\text { Limestone } \\
\text { shop }\end{array}$ & 0.35 & 0.3 & 5.44 & 5 & 7.05 & 7 & 2.71 & 2 \\
\hline $\begin{array}{c}\text { Electrical } \\
\text { service }\end{array}$ & - & - & 4.58 & 4 & 0.68 & 0.7 & 2.71 & 2 \\
\hline Boiler house & 7.92 & 8.2 & 16.33 & 17 & 1.27 & 1.3 & 5.41 & 6 \\
\hline Others & - & - & 3.71 & 3 & 18.1 & 18 & 52.89 & 54 \\
\hline
\end{tabular}

\section{Conclusions}

Current energy budget calculation represents simple computational task. Experience of current energy budget use for energy consumption and energy saving control allows to plan energy sources volume for different short periods of time more accurately, to calculate faults, to determine energy performance factors in terms of the year for fixed points based upon development prospect (or other side - production curtailment) and etc.

\section{References}

1. GOST 27322-87. Power plant balance. Main principles [in Russian]

2. GOST P 51379-99. Energy performance certificate of fuel and energy resources power consumer [in Russian] 
3. V.V. Litvak Zonal energy saving basis. (scientific, technical and industrial aspects) (STT, Tomsk, 2002)

4. G.N. Klimova, V.V. Litvak, Seven problems and seven keys of energy saving / Scientific Publication. Tomsk Polytechnic University (Red banner, Tomsk, 2013)

5. A.S. Nekrasov, Yu.V. Sinyak Power plant engineering control (Energiya, Moscow, 1979)

6. Yu.N.Savenko, E.O. Steinhaus Energy budget (Energiya, Moscow, 1971)

7. V.M. Simchera, Multivariate statistical analysis approaches (Finances and statistics, Moscow, 2008)

8. G.N. Klimova, V.V. Litvak, Industrial power engineering 7, 5 (2016) 